$8 \pi-2063$

UC-77

Reporting Date: December 1975

Issued: Fetruary 1976

\title{
Effect of Heat Treatment Temperature on Binder Thermal Conductivities
}

by

Paul Wagner 
Th: work was supported by the Energy Researcin and Development Administration: Division of Reactor Development and Demonstration.

Printed in the United States of America. Available from Naticnal Technical Intormation Service

U.S. Department of Coinmerce

5285 Port Royal Road

Spring field. VA 22151

Price: Printed Copy $\$ 4.50$ Microfiche $\$ 2.25$

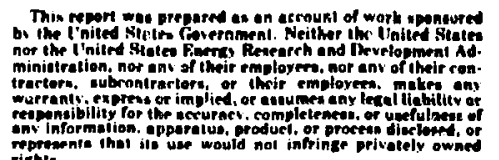

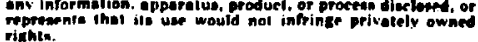




\title{
EFFECT OF HEAT TREATMENT TEMPEHATURE ON BINDER THERMAL, CONDUCTIVITIES
}

by

\author{
Paul Wagner
}

\begin{abstract}
The effect of heat treatment on the thermal conductivities of a pitch and a polyfurfuryl alcohol binder residue has bern investigated. Graphites specially prepared with these two hiriders were used for the experiments. Measured thermal conductivities were treated in terms of a two-component system, and the binder thermal conductivities were calculated. Both binder residues showed increased thermul conductivity with increased heat troatment temperature.
\end{abstract}

\section{INTKODUCTION}

Analysis of heat transter in the high-temperattire

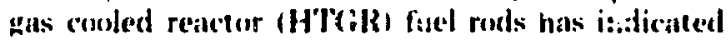
that increased thermal conductivity $(\lambda)$ in the linel rods would improve the therenal performances of the reactor eore significantly. ${ }^{1}$ Allowugh it has long been recognized that $x$ in artificial graphite can be affected by thermal treatment. cuantitative inlior. Ination about the effoct of heat treatment temperature on $A$ of traphites of interest was mut Io be found in the literafure. In particular, becouse HTCR fuel rods are made using pitch ar a similar binder, it is the thermal conciuctivity of the hinder residue that is of primary interest. Fxperiments per. formed to determine the binder $A$ as a function of hent treatmom temperature are descrihed in this repuri.

\section{EXPGRIMENTAI,}

As is sor oficen the 'ast' with graphites, it is diflicult (1) Pst ablish a single-valued cause-and-eflect experiment. This work was no exeeption. Direct $\lambda$ measurement in a specimen made using pitch or thermoxefting resin hinder (1he two candidat sos of interestl is an awkward task because pyrolysis and subsequent pralphitization with incregsing heat trentment tend in dograde the structural integrity of the sample. We decided to use compacts made from a well-graphitized graphite filler and a binder of interest. We reasuned thou because the filler had been araphitized at higher temperatures than thuse to be used in the $\lambda$ experiments, any increases in $\lambda$ would be due to changess in the $\lambda$ of the binder component only.

W. used two molded graphites. S.7 and S.8. Althength bot h were made of the same filler four, S-7 (ont ained 35 parts per hundred ( $p p h$ ) of pitch and $\mathbf{S}$. 8 contained $28 \mathrm{pph}$ of partially polymerized polytur. furyl alcohnl (PFA). "ataliged with 4t, maleic antudride. The specimens were hot-molded at 13.8 $M^{2}$ (2000 psi) $101173 \mathrm{~K}$ in graphite dies, then lakkc:: "s $1773 \mathrm{~K}$ in helium. Some properties of these geaphiles are as follows.

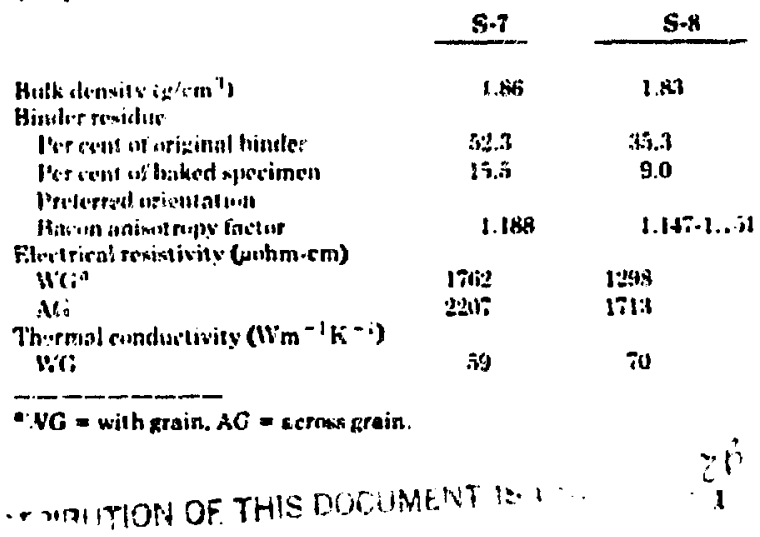


Fubr specimens were uned fur the study. ane ariemed with and one across the grain bi each

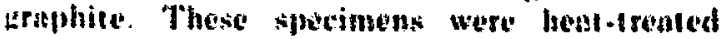
together: the treat ment comsisted of 3.,i-ks (1-h) ex. jesures in vacuum al 2014t, 2270, 2401, 26it, and 2 sitis $\mathrm{K}$.

The liwater assembly geometry is atuch that the tamperature uniformity within the samples and from sample to sample should be approximately o. s $k{ }^{3}$ The temperature accuracies are probubly within $5 \mathrm{~K}$ at the lowasi tomperalures and $\pm 1.5 \mathrm{~K}$ at the highest.

After eacl hest treatment. the samples were removel from the furnace and their thermal dif. fusivities were measured at som temperature. The llurmal diffusivity fol was obtained using a thermal iransion nother, and it is related to the sporimen dimensions by

$a=$ coustant $\times$ thickness ${ }^{2} \times\left(\right.$ tharacteristie $(\text { ime })^{-1}$

The thermal conductivity is ohtained from a by iss. ing:

$$
\lambda=n+15 .
$$

where $p=$ dersity and $C_{a r}=$ specific hent. During the course of the heat treatments, the densities and thicknessess whanged: so disl the sifecific hent, wh lawgh the anoumt of thange is difficult to assess. Therefore, we used a constont value, 0.721 if $n^{-1} K^{-1}$. for $C_{n}$. Linear interpolation hased on initial and final measurements wons usod at determise o and thickness after each heal treatment.

\section{RESEITS}

The thersul condutivities ubtaned are platted akainst heat-trentment tempernture in Fige. 1. As ex. pertud. A increases muntonienlly with heat. trot ment temperature. The rate of increase of $d$ with hent-Ireat ment cemperature is fastor in the pilch-bonded araphile than in that mode with PFA. This is more significant than the face that the $\lambda$ of the pitch-bonted meterial is lower. initially: thin that of the PFA graphite. This lower initial valte results from use of nomotimiand hinder. finur rat ion foll the experimenlal graphites. The seasons fint the steatler in the $\lambda$ data (i.e. a curve connecting the maints woukd lonk ' wavy") are nu clear: passibly it resules Irom the varims simplifying approximations uset in rolculating $A$.

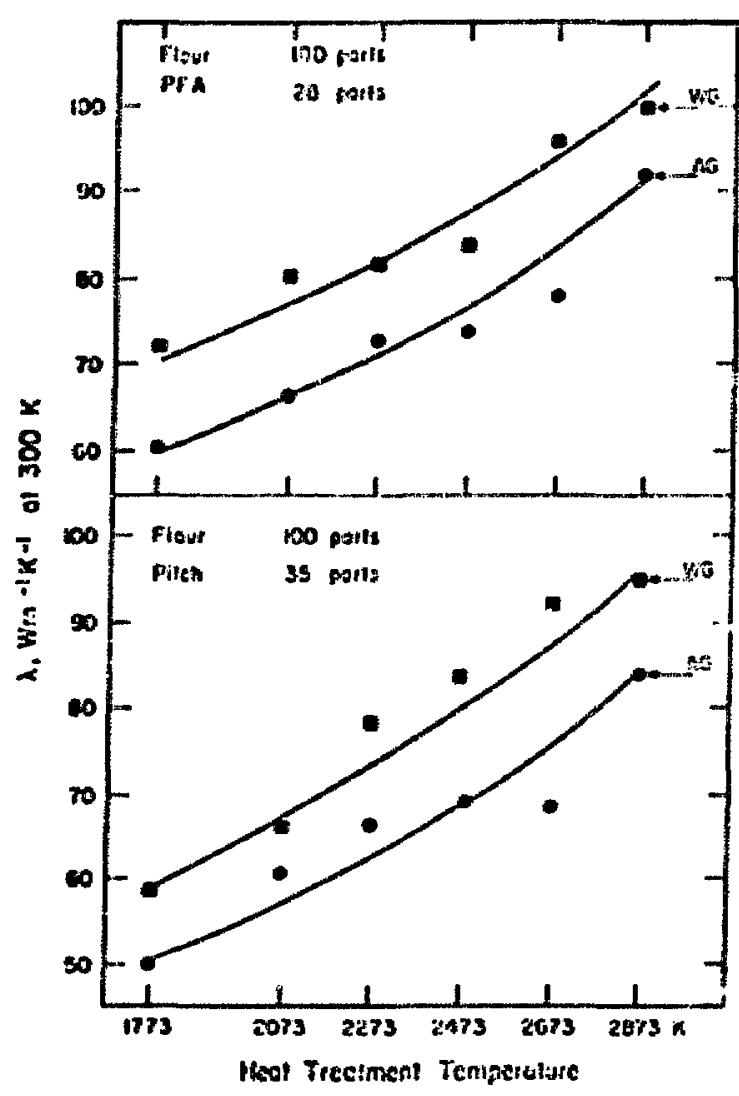

Fig. 1.

Hffet of heat treatment temperature on the

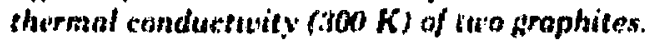

Tu determine the thernal conductivity chasuge in the hinder alone, we forst corrocted the measured $\lambda$ s for prorssity by usioge

$$
\lambda(\text { for } 100 \% \text { density })=\lambda \text { (measured }) \frac{2+p}{2(1-p)} .
$$

where $p=1-p / n_{1}=$ fractional purosity. $\rho=$ den . sily of the artifact, and on $=$ theoretical desssity. The cutculated $\lambda$ s were then used to abtain the hinder thermal canductivities by nssumiag that the grilphiles were :wil-phase systems in which the Emaphite particles were the dispersed "phase" and the binder was the continuous matrix. The thernal conductivity af the sustem is related to thesse of the coroponents by

$$
\lambda=\lambda_{b}\left[\frac{1-2 v_{g}\left(\lambda_{b}-\lambda_{g}\right) /\left(2 \lambda_{b}+\lambda_{g}\right)}{1+v_{g}\left(\lambda_{b}-\lambda_{g}\right) /\left(2 \lambda_{b}+\lambda_{g}\right)}\right] .
$$


where $\lambda_{1}=$ thermal conductivity of the binder (the cont imusoms phasel, $\lambda_{z}$ = lhezmal conductivily of the graphite (ahe dispersed platside). and $V_{6}=$ the velume fraction of the arrapbite. Becouse the araphite flem nad heen fully araphitized. $\lambda_{z}$ was assumed fo be 150 ) W/ank. The binder mass fraclions after pyrolysis were O. Lits in the pitch. and (1.19) in the PPA - Yonded arsaphite samples. respectively. Assumbing l hat thesse values nlso represented the volume fractions. $V_{E}$ wils 0.8 si in the pitch-bonded arnplute and 0.91 in that

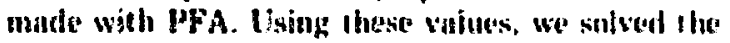
abrive coptution for $\lambda_{b}$.

The thermal conductivities of the swo binders are

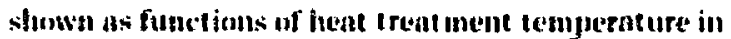
Pig. 2. P'ublisthed data on pilch residues' show $A$ att :Ax) $K$ in be about in $W^{-1} \mathrm{n}^{-1} K^{-1}$ is materials hent

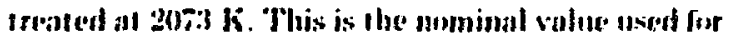
$x$ in the HTrik fuel ruds after 2073 k thermal treat.

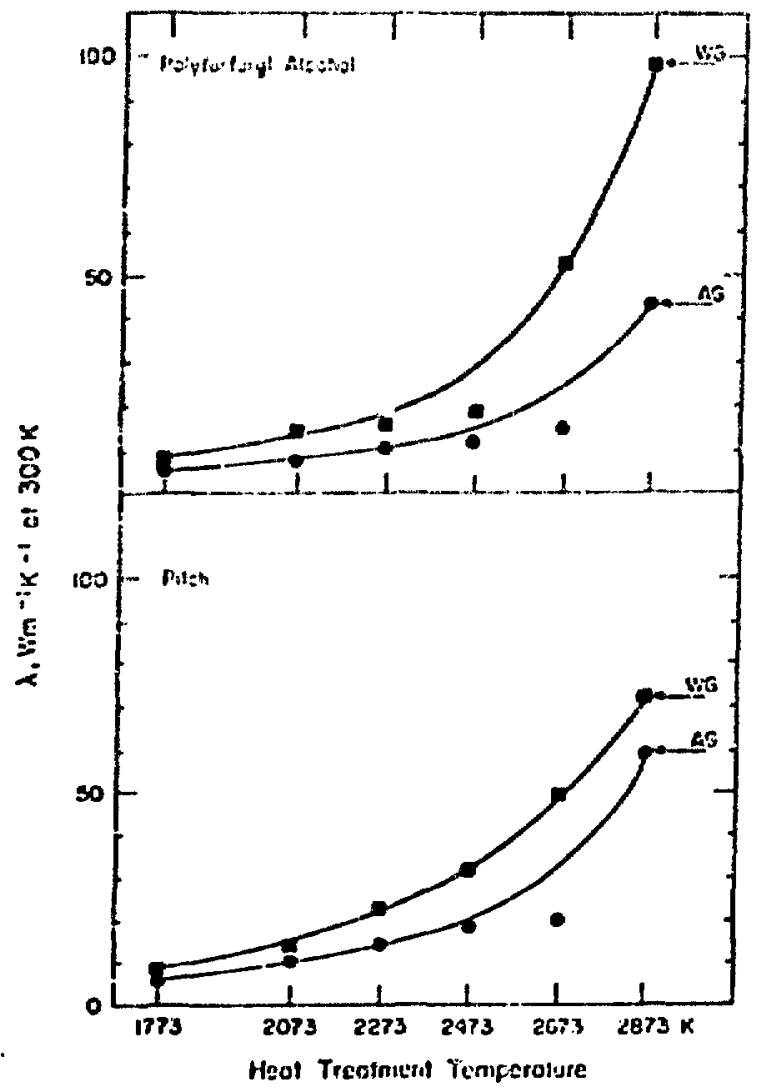

Fig. 2.

Effect sf heat treatment temperature on the thermal conductivity ( $3(K) \mathrm{K}$ ) of (uo binders. ment. Our values for pilch residue healed on $2073 \mathrm{~K}$ are 11 and $13 W^{-1} \mathrm{~m}^{-1}$. On the aterage, $\lambda$ value: for the PFA hinder residue are lower than corm. paratsle values for the piteh bintler. This is to be expected bucause the nutural product (pitch) tends to fersuphitize more readily than the synthet ix polymer at these temperatures. As Fig. 2 shows. heat treat. ment affects the thermal conductivitios of the hinders cery markedly. Bowh binders are affected abeut equally $(A$ increases of $7-10 \mathrm{X}$, by the thertinal Ireatment.

\section{SUMMARY}

Ascerlions that increasing graphote hinder mrersissing temperatuses impreses their thermal sunductivity have been verified. Within the limitimposed by sur experimental and calculational ap-

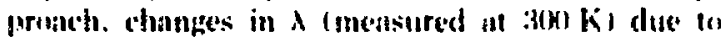
changes in heat treatment tempernture have been quamtified.

\section{ACKNOWI.FDGMENTS}

The graphites were made expressly tor these experiments by R. J. Impresecia of lans Alatmoss Scien.

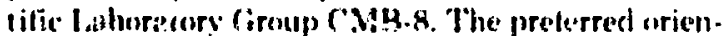
lation medsurements were b. J. A. O'Rlurke if (MH.s. The aulhor is: indebled to thene resentehers for their aid in this projert.

\section{RBPBHENCWS}

1. J. D. Balcomb and P. Wazner. "Fxtending the" Temperature Range of the H'll," Proc. HeSEs Intern. Conf., I andon (Now. 26. 1973).

2. 1'. Winguer and I.. B. Dinueleberg. "Simme Thor. mal Properties of a Palufurliury! Alcohal Bunded Cinphite." Carbon 7. 273) 1194991.

a. P. Wagner. "A Versat ile High Temperature Furnace." Res. Siri. Instr. \&. 10is (196ii).

1. P. Waner and 1. B. Diuchsherg. "Thermal conductivity of \%'A Giaphite." Carlon 5 (196iT).

¿. P. Wagner. J. A O'Runrke. and P. F. Armstrong. "Pornsity Elfects in Polveryotalline Graphite." I. Am. Ceram. Snc. 55. 214 (1972). 
6. S. C. Cheng and R. 1. Vachon, "The Prediction of the Thermal Conductivity of Two and Three Phase Solid Heterogenerus Mixtures," Int. J. Heat Mass Transfer 12, 249 (1969).
7. Thermophysical Properties of Matter, Vol. 2, Y. S. Touloukian et al., Eds. (Plenum, New York. 1970). 